\title{
Peculiarities of Using Biomass for Oil-Contaminated Soils Remediation in the Far North Regions
}

\author{
Gagloeva $A E^{1^{*}}$ and Aistov IP
}

\author{
Department of Technical Sciences, Omsk State Technical University, Russia
}

\begin{abstract}
The problem of oil-contaminated soils remediation in the Far North regions is considered. The need in the destructed areas restoration is demonstrated. A review of existing conventional methods for the destructed areas restoration consisting of two stages: Technical and biological, is carried out. The main complex of technical remediation activities and the stages of biological remediation are described. Besides, the inefficiency of using the conventional method in the regions of the Far North is estimated. Modern bioengineering technologies for the destructed areas restoration are presented. The expediency of using biomass for the destructed areas remediation is described in detail. The technology of biomass application is analyzed. A comparative analysis of the conventional and biomass-using restoration costs for the destructed site exploration well R-2012 of CJSC “Arktikgazstroy”, the Yamalo-Nenets Autonomous District, is carried out.
\end{abstract}

Keywords

Destructed areas remediation, Bioengineering technologies, Biomass

\section{Introduction}

At present, the issue of oil-contaminated areas remediation remains urgent. Everyone understands the need to restore the productivity and environmental functions of the soil, which natural characteristics are violated when hydrocarbons penetrate its surface. The consequences of irrational farming and territory development are often felt by ecosystems. The main task of oil-contaminated areas remediation is to reduce the content of oil products in the soil to the level stated in the regional standard.

The most sensitive to external influence are natural complexes of the Far North, where vegetation is extremely vulnerable under mechanical disturbances. The time for the communities' restoration is measured in dozens of years. It is not just a very slow growth of plants. The whole biogeocoenosis is very fragile, too: Even small disturbances of the vegetation cover in most cases cause changes in the soil and the regime of its moistening. Therefore, during the territories remediation in the Far North, the requirements of local authorities as well as the recommendations of scientific and production associations are taken into account [1].

The purpose of this work is to analyze the possibility of using biomass in the remediation of oil-contaminated lands in the Far North.

All the areas destructed by the construction, where there were changes expressed in the change in the hydro-geological regime of the territory (drying up, under-flooding), disturbance and decrease in the productivity of the soil cover, and in the formation of new relief forms, are subject to remediation [2]. However, due to the difference in natural and climatic conditions in different regions of the country, regional requirements for areas remediations are specified.

The conventional method of oil-contaminated areas remediation in the Far North regions includes two stages: Technical and biological [3]. The technical stage is aimed at the restoration of the conditions close to

\footnotetext{
*Corresponding author: Gagloeva AE, Professor Assistant, Department of Technical Sciences, Industrial Ecology and Security, Omsk State Technical University, Russia, E-mail: anzhelika.gagloe@mail.ru
}

Received: July 26, 2017; Accepted: May 29, 2018; Published online: May 31, 2018

Citation: Gagloeva AE, Aistov IP (2018) Peculiarities of Using Biomass for Oil-Contaminated Soils Remediation in the Far North Regions. J Soil Water Sci 1(1):26-28

Copyright: (C) 2018 Gagloeva AE, et al. This is an open-access article distributed under the terms of the Creative Commons Attribution License, which permits unrestricted use, distribution, and reproduction in any medium, provided the original author and source are credited. 
Citation: Gagloeva AE, Aistov IP (2018) Peculiarities of Using Biomass for Oil-Contaminated Soils Remediation in the Far North Regions. J Soil Water Sci 1(1):26-28

natural ones, localization and elimination of emergency spills of hydrocarbons by removing the contaminated soil on the entire area of the oil spill, followed by the purification in industrial plants or at special sites, replacing it with clean fertile soil, and subsequent execution of preparatory works for biological remediation.

Technical remediation activities are carried out by using a mechanized method - a bulldozer, an auto-grader and an excavator equipped with bucket-planners [4].

In accordance to the "Regulation" [5], the biological remediation technology includes measures for the artificial restoration of the fertile soil layer and vegetation cover formation.

Biological remediation activities are carried out in two main stages:

Stage 1: Pre-sowing preparatory activities (agro-technical works).

Stage 2: Fixing the bulk base of the well site (sowing grasses).

In the Yamalo-Nenets Autonomous District, on the areas with destructed vegetation cover, their restoration by perennial grass species adapted to local conditions is recommended. This means that the remediation of the destructed sites is planned by the method of creating grass-covered areas using turf, as it contributes to the creation of favorable conditions for the soil microflora development [6]. Moreover, its thickness should be at least $12 \mathrm{~cm}$ when commissioning. This condition requires land users to conduct additional work on finding turf quarries, processing and obtaining the necessary permits. This hinders the process of carrying out restoration work and jeopardizes the timely return to the state commission's land. In addition, the existing disturbed areas remediation technology in the Yamalo-Nenets Autonomous District is very laborious and costly.

Recently, new bioengineering technologies have appeared on the market to restore soils and bring the territories to a suitable state for their further use. Taking into account that the priority task of a large company is efficient, fast and high-quality construction and reconstruction of the facilities with the least material costs, simple, technically and economically advantageous materials are required. Nowadays, such material is biomass.

Biomass is a cloth made from vegetable fibers (straw, coconut fiber or their mixture), reinforced by polypropylene or jute thread [7]. Biomass is a two-layer, completely biodegradable base. Between the layers, there is a remediation mix including seeds of perennial plants, nutrients (mineral and organic fertilizers, plant growth stimulants, soil-forming bacteria) and water-retaining components (in the form of synthetic polymers) that

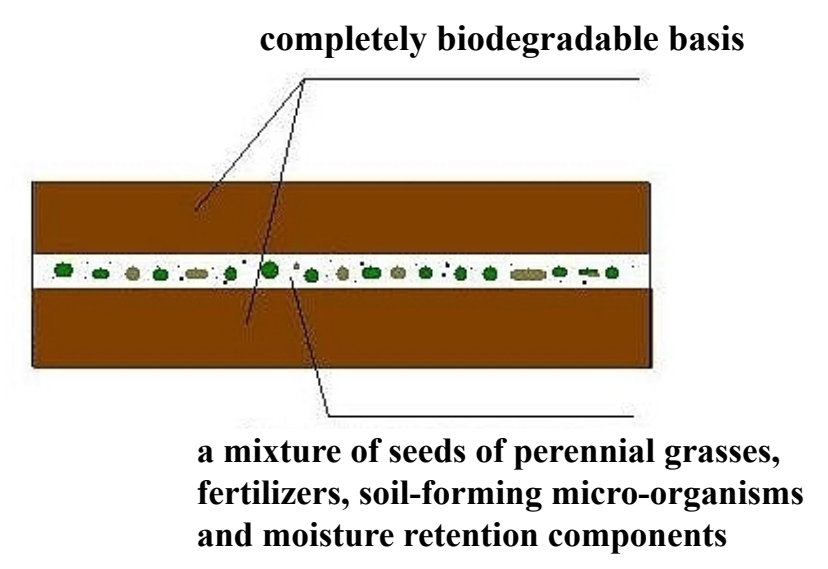

Figure 1: Structure biomat.

improve soil capacity to retain moisture (Figure 1).

Remediation mixture in each specific case is selected based on the climatic, soil and hydrological conditions of the area of biomats application. The use of biomats allows the soil-vegetation layer to be restored during the first summer season without deposing a fertile soil layer and subsequent sowing of grass [8].

At first, during the development of plants, the biomass performs protective functions, including erosion processes prevention. Within 2-3 years, by the time of the formation of a uniform grass stand with a copious root system, which penetrates deep into the soil, it binds the soil and forms a sod. The resulting turf cover has a high mechanical strength; in addition, due to water-holding components, the water regime of the soil layer improves.

At present, different types of biomass have been developed. They are used for different purposes: From fixing the soil surface and preventing erosion, restoring the vegetation cover in places of the soils chemical contamination, to remediation of flooded, swamped or sandy soils under adverse climatic conditions [9].

Biomass laying is carried out on a pre-planned and leveled ground surface. To ensure a close fit of the material to the surface, it is recommended to remove individual stones and clods of soil. Laying the biomass is best done at air temperatures of $+5{ }^{\circ} \mathrm{C}$ and above. The most favorable time is the beginning of the spring-summer period. The biomass is spread along an inclined ground surface in the transverse or longitudinal direction, depending on the width of the area to be protected. The roll width is about $2 \mathrm{~m}$, the joint of the material strips is recommended to overlap by $10-15 \mathrm{~cm}$. For the reliability at the joints, the biomass strips should be fastened to the bulk ground with special staples or L-shaped anchors made of small diameter armature or metal wire. After the laying, the biomass is dusted with local or imported sandy or fine-clay loamy soil [10]. The 
Citation: Gagloeva AE, Aistov IP (2018) Peculiarities of Using Biomass for Oil-Contaminated Soils Remediation in the Far North Regions. J Soil Water Sci 1(1):26-28

Table 1: A comparative analysis of the remediation costs for the disturbed area at the site of R-2012 exploration well of CJSC "Arktikgazstroy", the Yamalo-Nenets Autonomous District of the conventional method and of the biomass -using one. The results are shown.

\begin{tabular}{|c|c|c|c|}
\hline \multicolumn{2}{|l|}{ Turf-using remediation technology } & \multicolumn{2}{|c|}{ Biomass -using remediation technology } \\
\hline Activities & Expenses, rub. & Activities & Expenses, rub. \\
\hline 1. Turf quarry survey & $3,00,000$ & $\begin{array}{l}\text { 1. Technical remediation stage of } \\
\text { the exploration well R-2012 site } \\
\text { (including. sludge pit disposal) }\end{array}$ & $11,91,8326$ \\
\hline $\begin{array}{l}\text { 2. Registration of necessary permits for the turf } \\
\text { quarry (land surveying, land lease contracts) }\end{array}$ & 45,000 & 2. Biomass purchasing & $36,80,000$ \\
\hline $\begin{array}{l}\text { 3. Project of turf quarry development and } \\
\text { remediation }\end{array}$ & $3,50,000$ & $\begin{array}{l}\text { 3. Biomass shipping to Novy } \\
\text { Urengoy }\end{array}$ & $5,00,000$ \\
\hline $\begin{array}{l}\text { 4. Technical remediation stage of the exploration } \\
\text { well R-2012 site (including. sludge pit disposal) }\end{array}$ & $11,918,326[1]$ & 4. Biomass laying and dusting & $1,84,731$ \\
\hline $\begin{array}{l}\text { 5. Biological remediation stage of the exploration } \\
\text { well R-2012 site (including turf exploration and } \\
\text { transportation) }\end{array}$ & $32,85,859$ & 5. Unforeseen expenses & $2,52,050$ \\
\hline $\begin{array}{l}\text { 6. Other expenses (winter appreciation, time } \\
\text { expenditure, unforeseen expenses) }\end{array}$ & $18,511,82$ & & \\
\hline 7. Turf quarry remediation & $5,00,000$ & & \\
\hline Total & $18,250,367$ & & $16,535,107$ \\
\hline
\end{tabular}

layer thickness should not exceed 3-4 cm. If the rules for biomass rolls laying are complied with, full landscaping of the territory occurs within one to two months.

As an example, consider a comparative analysis of the remediation costs for the disturbed area at the site of R-2012 exploration well of CJSC "Arktikgazstroy", the Yamalo-Nenets Autonomous District of the conventional method and of the biomass -using one. The results are shown in Table 1.

In conclusion, it should be noted that the problem of oil-contaminated soils remediation in the Far North regions were described. This research showed that the biomass remediation seems to be promising in the Far North regions. The technology of biomass application was analyzed. A comparative analysis of the conventional and biomass-using restoration costs for the destructed site exploration well R-2012 of CJSC "Arktikgazstroy", the Yamalo-Nenets Autonomous District, was carried out.

Thus, in accordance with the stated characteristics, the biomass is an effective bioengineering material capable of quick and qualitative restoring the destructed areas along with the conventional method of remediation in the regions of the Far North. The remediation technology by biomass laying is easy to use and does not require additional research and development of turf quarries.

One of the undeniable advantages of using biomass is its complete uptake in the soil. The biodegradable layers make it environmentally safe. In addition, the biomass is simple in packing and does not require further special care.

If comparing the costs of two remediation technologies, a biomass method is economically advantageous for companies. It saves time, which is now spent on pro- cessing permissive documentation for turf quarries and developing and coordinating the remediation projects. Thus, we can say that the use of biomass for recultivation of disturbed lands in the far North regions is the most efficient way to restore the land.

\section{References}

1. Cherkova NM (1985) Ecological basics for the reclamation of lands. Moscow, Nauka, 183.

2. (2002) The regulations of the organization of work for the protection of the environment during the construction of the wells-introduced. M: VNIIGAZ 98s.

3. GOST 17.3.04-83. Protection of nature. of the earth. Requirements.

4. Krayushkina EG (1997) Legal regulation of reclamation of lands disturbed in the process of subsoil use/ Abstract. Diss. on competition academic degree in law Institute of legislation and comparative jurisprudence under the Government of the Russian Federation. 26s.

5. Motorina LV (1975) Experience the disturbed industry landscape. M: VNIITTE ISX 84s.

6. Olenkov VD (1988) Creation of artificial terrain in parks and recreation areas, designed in disturbed areas. Express information. 4: MGZNTI 6s.

7. Smetanin VI (2000) Reclamation and construction of disturbed lands. M Kolos, 96s.

8. (1996) Technology of recultivation of anthropogenic disturbed lands in the Yamal-Nenets Autonomous region//Russian Academy of agricultural Sciences. Siberian branch. Novosibirsk. 24s.

9. Cherkova NM (1985) Ecological basis for the remediation. Moscow, Nauka, 183s.

10. Chibrik TS (2002) Fundamentals of biological reclamation: Textbook. manual. Ekaterinburg: Izd-vo, Ural University, 172s. 